\title{
Síntesis de las artes en la Capilla de Ronchamp
}

\section{Resumen}

¿Son transferibles las artes entre sí?, ¿un mismo objeto podría deambular por diferentes campos como la pintura, la arquitectura y la escultura? El artista-arquitecto Le Corbusier demuestra que estos ámbitos del arte se entremezclan y fusionan en la Capilla de Ronchamp (1950), tal vez su obra más personal. En este texto vamos a sondear cómo a través de los ejercicios alternos de la pintura y la escultura, el maestro francosuizo lograba sintetizar, en una especie de laboratorio de experimentación formal, su arquitectura. Para ello se basaría en la observación de la naturaleza, en experiencias aprendidas en sus viajes —especialmente en su viaje formativo por Oriente (1911)—, en técnicas que compartiría con otros artistas, e incluso en temas mitológicos. La metodología empleada consistió principalmente en comparar buena parte de los escritos referidos hacia el arte y de la producción plástica de Le Corbusier (pintura, escultura y arquitectura), poniéndolos en relación con la Capilla. Al final podremos percatarnos que, en efecto, La Capilla de Ronchamp es el resultado de un largo trasegar por diferentes áreas del arte, en el cual las distintas experiencias plásticas llegan a fundirse en algo que Le Corbusier denominó "La síntesis de las artes". Este laboratorio formal devendría luego en el descubrimiento de una clase de espacio diferente al hasta ahora reconocido, "el espacio indecible", un espacio metafísico en el cual la obra de arquitectura y su entorno establecen una estrecha comunicación.

\author{
Jaime Alberto Sarmiento \\ Ocampo \\ Doctor en Arquitectura \\ Profesor asociado Universidad \\ Nacional de Colombia sede Medellín \\ Medellín, Colombia \\ Correo electrónico: \\ jsarmien@unal.edu.co \\ 주 orcid.org/0000-0002-5588-5956 \\ Google Scholar
}

Recibido: octubre 05 de 2018 Aprobado: febrero 24 de 2020

Palabras clave:

arquitectura, pintura, escultura, acústica visual, espacio indecible. 


\title{
Synthesis of the arts in The Chapel of Ronchamp
}

\begin{abstract}
Are the arts transferable to each other? Could the same object roam through different fields such as painting, architecture and sculpture? The artist-architect Le Corbusier shows that these areas of art intermingle and merge into the Chapel of Ronchamp (1950), perhaps his most personal work. How, through the alternate exercises of painting and sculpture, the French-Swiss master managed to synthesize his architecture in a kind of formal experimentation laboratory, will be presented in this text. To do so, the artist would be based on the observation of nature, on experiences learned in his travels - especially in his formative journey through the East (1911) — or on techniques he would share with other artists, and even on mythological themes. The methodology used consisted mainly in comparing a good part of the writings related to the art and plastic production of Le Corbusier (painting, sculpture and architecture), relating them to the Chapel. In the end, it will be seen that, in fact, The Chapel of Ronchamp is the result of a long journey through different areas of art in which the different plastic experiences come to merge into something that Le Corbusier called 'The synthesis of the arts'. This formal laboratory would later become the discovery of a kind of space different from the one previously recognized, "the unspeakable space", a metaphysical space in which the work of architecture and its surroundings establish a close communication.
\end{abstract}

Key words:

architecture, painting, sculpture, visual acoustics, unspeakable space. 


\section{Introducción}

Menos difundida que sus reconocidas actividades como escritor, arquitecto y urbanista, la pintura tiene una gran importancia cuando se trata de entender la obra del maestro. En sus pinturas, Le Corbusier vertía profusamente sus pensamientos más íntimos y personales; fueron, en muchos de los casos, el laboratorio donde se germinaba su arquitectura. Una vez consultado en una entrevista por su amigo Jean Petit, sobre la clave de su creación artística, éste respondió:

En verdad, la clave de mi creación artística es mi obra pictórica, comenzada en 1918 y continuada regularmente cada día (...) El fondo de mi búsqueda y de mi producción intelectual tienen su secreto en la práctica ininterrumpida de la pintura. Es ahí donde hace falta encontrar la fuente de mi libertad de espíritu, de la independencia, de la lealtad y la integridad de mi obra. (Petit, 1968, p. 160)

El pintar para Le Corbusier era un acto privado, casi íntimo. Solitario, se encerraba a pintar casi a diario en el estudio ubicado en su propio apartamento, el cual solía llamar de la "investigación paciente", sin permitir que nadie le molestara (Wogenscky, 1987, p. 25). Para el artista, el pintar representaba una labor personal, era manifiesto el celo y el cuidado que mantenía para no revelar el significado de sus cuadros: "Nunca en mi vida 'he explicado' una pintura" (Le Corbusier, 1957, p. 7). El pintar se trataba para él de una actividad tan íntima, que revelar sus fuentes sería tanto como traicionarse a sí mismo y, tal vez, ponerse en evidencia:

La Pintura es una batalla terrible, intensa, despiadada, sin testigos: un duelo entre el artista consigo mismo. La batalla está en el interior, adentro, desconocida por fuera. Si el artista la cuenta es un traidor con respecto a sí mismo. (Le Corbusier, 1981, p. 506) 
La pintura, escultura y arquitectura en las manos de Le Corbusier irían perdiendo sus límites hasta mezclarse en algo que él llamó "Síntesis de las artes". Una pintura podría convertirse en una escultura, y la escultura en un edificio, y el edificio ser fuente de una nueva pintura.

¿Pero dónde comienza la escultura, dónde comienza la pintura, dónde comienza la arquitectura? En las extremidades de estas tres ramas se encuentra la estatua, el cuadro, el palacio o el templo. Pero al interior del cuerpo mismo del evento plástico todo no es más que unidad; escultura-pintura-arquitectura: Volúmenes (esferas, conos, cilindros, etc...) y policromía, es decir materiales, cantidades, consistencias específicas ensambladas en relaciones de una naturaleza emocionante. El cuerpo del ámbito edificado es la expresión de las tres artes mayores solidarias. (Le Corbusier, 1948, p.11)

En el caso de la Capilla de Ronchamp (figura 1), es posible rastrear un proceso que comenzó a finales de los Treinta a partir de, básicamente, dos series de pinturas. Una comenzaría en 1939 con la serie titulada Ozon y que a mediados de los Cuarenta se Ilamaría Ubu. La otra comienza en 1944 con la pintura Portrait de Femme à la cathédrale de Sens, la cual sería el origen de la serie Icône. Estas dos ramificaciones confluirían en la serie Taureaux de principios de los Cincuenta. Algunas pinturas de la serie Ozon y Ubu las realizaría en escultura a partir de 1947; esculturas que él Ilamaría "acústicas" (Coll, 1994). 


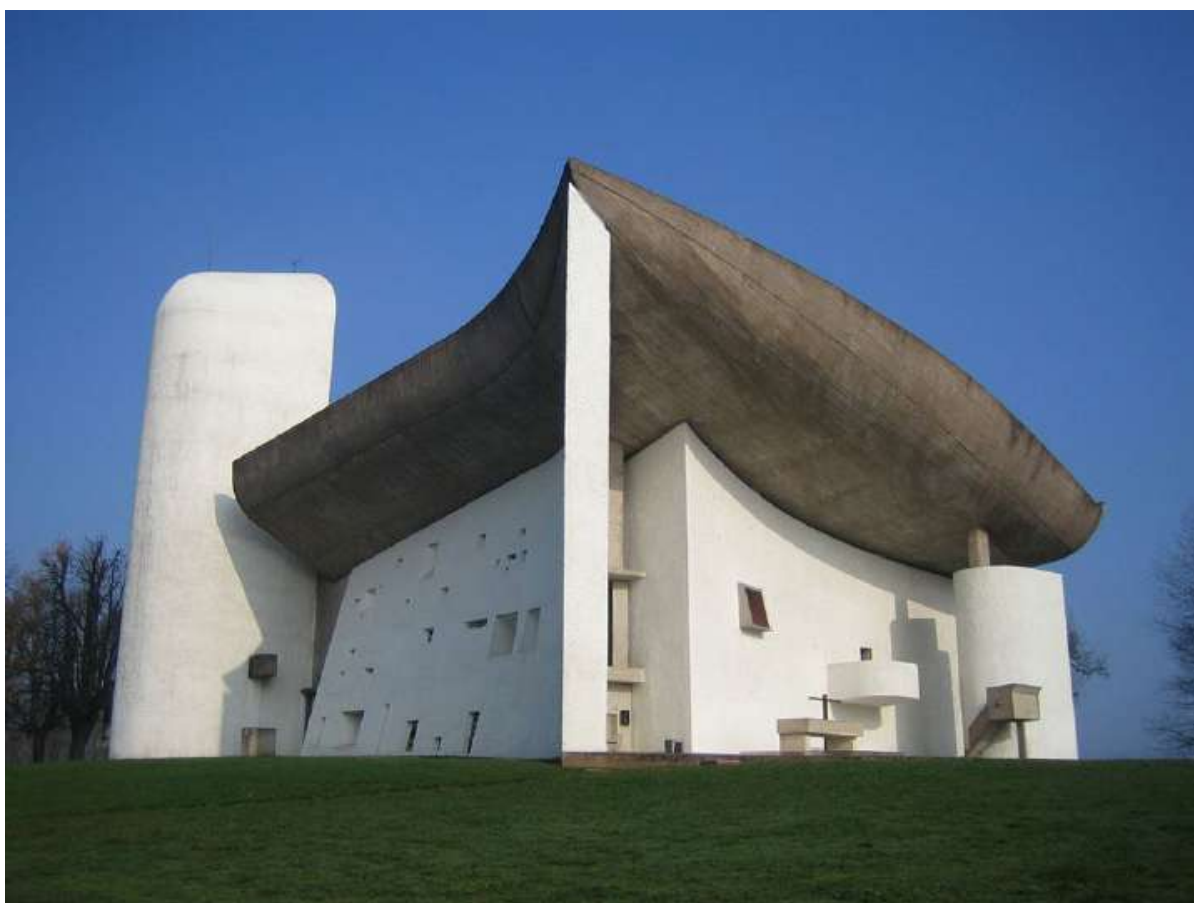

Figura 1. Capilla de Ronchamp. Fuente: foto del autor.

\section{La pintura}

Animado por su entonces amigo Amédée Ozenfant, Le Corbusier comenzó a pintar en 1918. En un principio lo hacía durante los fines de semana y luego, casi religiosamente, pintaba día a día de 7 a 13 en el taller de su apartamento de la Porte Molitor (las tardes eran reservadas a la arquitectura y el urbanismo en el taller de la Rue de Sevres). Al final de su carrera la pintura se vio supeditada 
al tiempo que le permitían sus constantes viajes; realizaba los bocetos a bordo de aviones o barcos, o en su cabaña vacacional de Cap Martin.

De la mano de Ozenfant, el joven aprendiz comenzó pintando bodegones de objetos que denominaba 'tipo': guitarras, botellas, vasos, platos... cosas que en su momento Le Corbusier reconoció como intrascendentes, hasta que aproximadamente en 1927 comenzó a introducir objetos evocadores, "Objetos a reacción poética", como guijarros, conchas, piedras, huesos... cosas cotidianas que encontraba en el camino y que llamaban poderosamente su atención.

Estos fragmentos de elementos naturales, piezas de piedra, fósiles, trozos de madera, estos objetos martirizados por la naturaleza, se reúnen en el borde del agua, el lago, el mar... expresando leyes físicas, desgaste, erosión, explosión, etc. No solo tienen cualidades plásticas, sino también un extraordinario potencial poético. (Le Corbusier, en Hervé, 1970, p.12)

Comenzando los años treinta, con la impresión aún viva de sus viajes por América y Argel, reaparece con gran fuerza el componente de la figura humana; ésta, generalmente comparte la escena con los "objetos a reacción poética". Principalmente pinta figuras femeninas: "Solo dibujé o pinté mujeres, o imágenes, o símbolos, o geologías de mujeres" (Le Corbusier, 1956).

La serie ICône, que comienza pocos años antes de la Capilla, se inicia a partir de una pintura titulada Portrait de femme à la cathédrale de Sens, (1944) (figura 2). Se trata de una mujer con las manos entrelazadas, en gesto de plegaria. Le Corbusier le cuenta a su amigo Constantino Nivola que se inspiró en una mujer que vio rezando en la catedral de Sens:

Me impresionó la concentración natural del simple ritual expresado en el gesto de sus manos con los dedos entrelazados, la mesa baja con velas y las amplias formas de su pecho y su cabeza mirando francamente el objeto invisible de su fe. (Ingersoll, 1990, p. 12) 


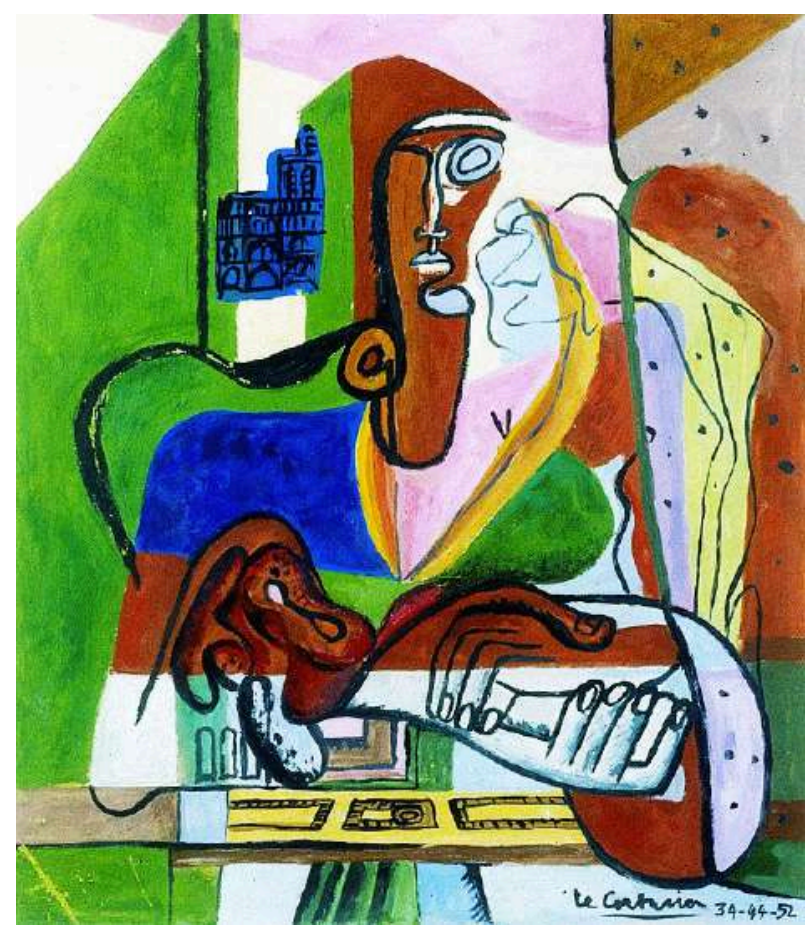

Figura 2. Portrait de femme à la cathédrale de Sens (1944). Fuente: Fondation Le Corbusier (1997).

La pintura sufrió múltiples transformaciones, pero en general conservó las partes esenciales: un rostro de mujer, las manos entrelazadas, un cirio al costado de las manos y unos grandes pechos (figura 3). Ya no tenía las manos sobrepuestas una encima de la otra, sus dedos se entrelazaron en un ovillo siempre inclinado, siguiendo la diagonal que hacía un velo en el primer cuadro. Las dos manos, junto con un brazo y un hombro, se convirtieron en un elemento que hacía un ocho: dos bulbos en los extremos unidos en un cuello estrecho. La silueta del 
tronco se volvió particular: uno de los senos se veía de frente, con el pezón en la parte baja — en algunas ocasiones era la llama del cirio—, mientras que el otro seno, que se veía de costado, se disparaba con tal fuerza hacia arriba que formaba una punta, una de las tres puntas que coronaba el tronco. En la punta intermedia se balanceaba el rostro - a veces de una luna.

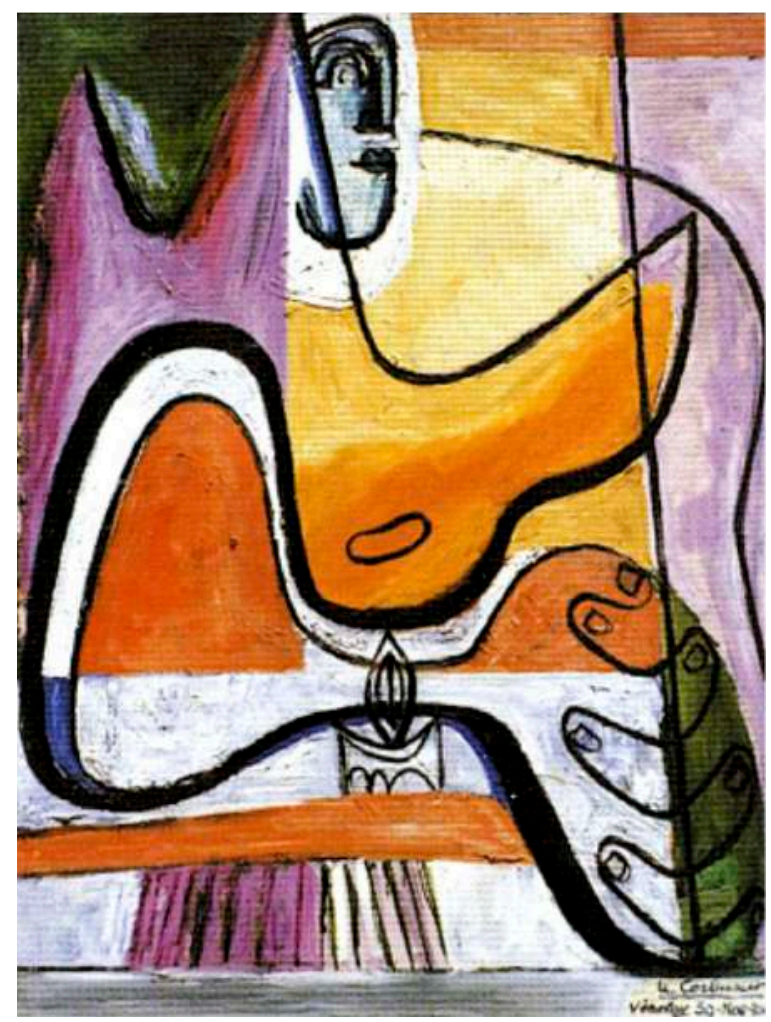

Figura 3. Pintura de la Serie Icône (1950). Fuente: Fondation Le Corbusier (1997) 
El nombre de la serie lo tomaría de su mujer Yvonne — se trata de un juego de palabras entre Yvonne e Icône-. Refiriéndose a ella, como si se tratara de un icono sagrado, esto dice Le Corbusier en una de sus publicaciones: "En mi Poema del ángulo recto ella ocupa el lugar central" (Le Corbusier en Petit, 1957, p. 121). En este libro, que realiza entre 1947 y 1953, reúne lo más granado de su propio repertorio iconográfico. En efecto, en el cuadrado intermedio del arreglo global de imágenes (casilla E3), una especie de diagramación similar al juego de la rayuela, denominado por él "iconostasio" (nombre que se le da al lugar sagrado de la religión griega ortodoxa) aparece la figura de lcône.

En el año 1948, Le Corbusier pinta un trozo del mural en el Pabellón Suizo a partir de este motivo (figura 4). El mural está dividido en diferentes episodios, 4 personajes que proceden de diferentes series de pinturas. Los dos de la izquierda son figuras masculinas y los de la derecha femeninas. El primero a la izquierda es una selección de guijarros, maderas y piedras; objets à réaction poétique, que forman la cabeza de un toro. El segundo es interpretado como un autorretrato (Moore, 1979). La tercera es Yvonne-Icône. Y la cuarta es una mujer alada con cabeza y cuernos de cabra, sostenida por una gigantesca mano. En el mural, el rostro de Icône se cambia por el de una luna que se balancea en el pico intermedio. Richard Moore hace un estudio interpretativo de este mural. Según él, la tercera figura representa una narración de la mitología griega en que la diosa Luna está relacionada con los cuernos de un toro:

Esta configuración fundamental, que es crucial para los ambiciosos esquemas simbólicos de la producción de Le Corbusier en todas las áreas, parece representar a la luna en su menguante creciente, mirando a la derecha hacia la temporada invernal de Capricornio. Las tres puntas, que hacen eco de los cuernos de los toros de la izquierda, representarían entonces el conocido mito de la luna como una diosa con cuernos relacionada con el toro, que proporcionó uno de los mitos cosmogónicos arquetípicos en la evolución de la mitología griega primitiva. (Moore,1979, p. 13) 


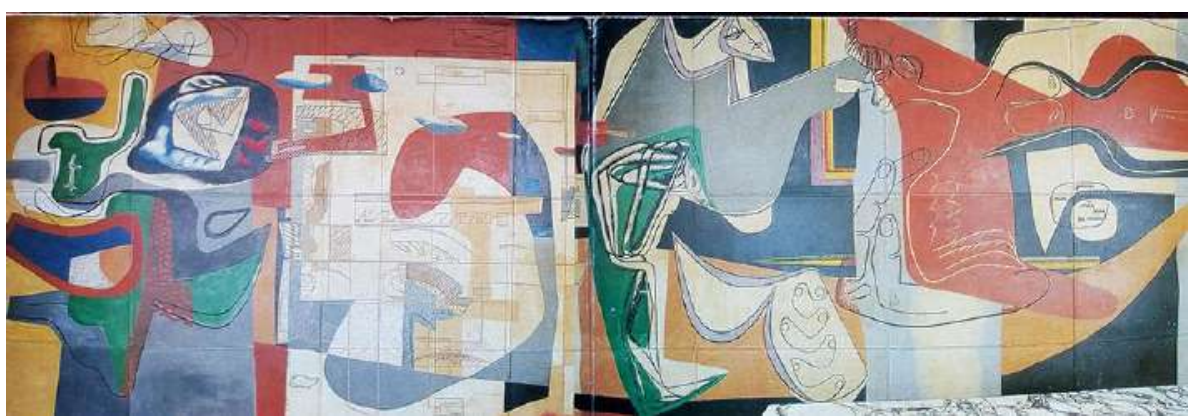

Figura 4. Mural Pabellón Suizo (1948). Fuente: Fondation Le Corbusier (1997).

La Diosa Luna también se ve relacionada con la Capilla. En uno de los carnets de viaje de Le Corbusier aparece esta figura entremezclada con las torres y la cubierta de Ronchamp (figura 5). El pico de la izquierda tiene el perfil de la torre vista de costado. Incluso se insinúa como un elemento vertical. Detrás del rostro de la luna, sombreada, se ve otra torre vista por detrás. El pico de la derecha semeja el perfil de la cubierta que se dispara hacia arriba. Si nos detenemos en la unión entre el rostro de la luna y el pico intermedio, descubriremos la proa de la Capilla (el punto sureste en que confluyen las líneas de muros y cubierta). La parte de arriba del dibujo reproduce el paisaje superior de Ronchamp. 


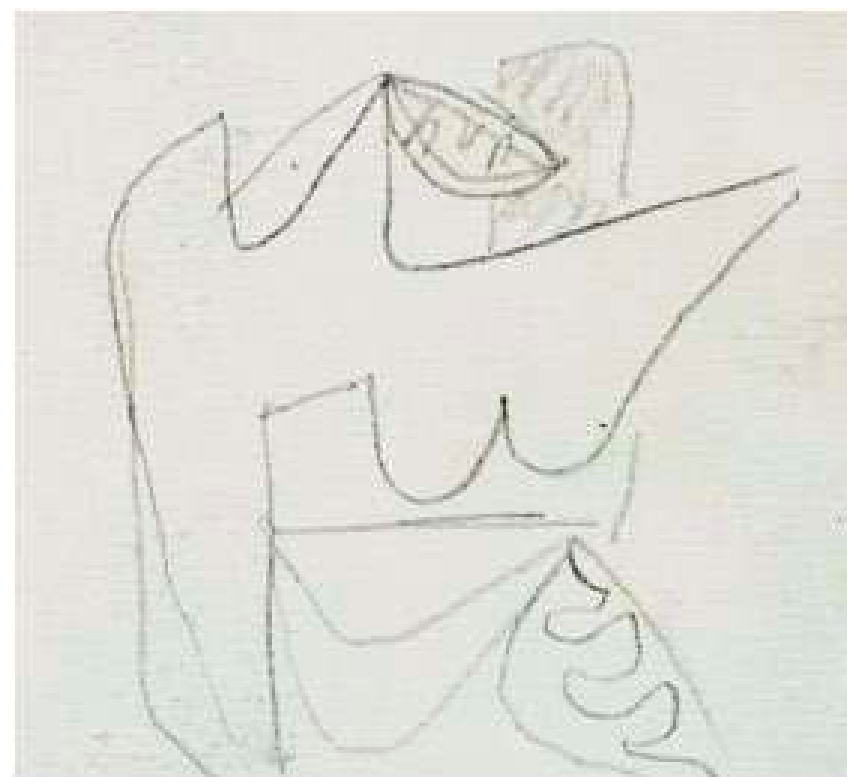

Figura 5. Dibujo de la Diosa Luna relacionado con la Capilla de Ronchamp (1952). Fuente: Fondation Le Corbusier (1981), Carnet F 24, 707.

La forma de las torres de la Capilla también está muy relacionada con una pintura de Le Corbusier, titulada Ançores de 1946 (figura 6), precedente a la serie Icône, en la que se ve la figura femenina con las manos entrelazadas. La cabeza de la mujer tiene una cierta similitud con la silueta de las torres de Ronchamp (figura 7). La mujer tiene un rostro plano, de nariz recta — son como el frente y la ventana vertical de la torre-, el mentón es igual al trazado en planta de la torre. Parece estar mirando lejos. La cabeza está pintada en escorzo y coincide en mucho con la silueta de la torre vista en escorzo: el rostro de la mujer y el frente de la torre caen en un plano vertical, marcando un quiebre con la cabellera y la cubierta, que se derraman hacia atrás con 
una suave pendiente, para luego bajar en vertical. Las torres resultan siendo una referencia antropomórfica hacia la figura femenina expresada en la pintura. Cuadro y edificio, pintura y arquitectura se van entrelazando, se van nutriendo mutuamente.

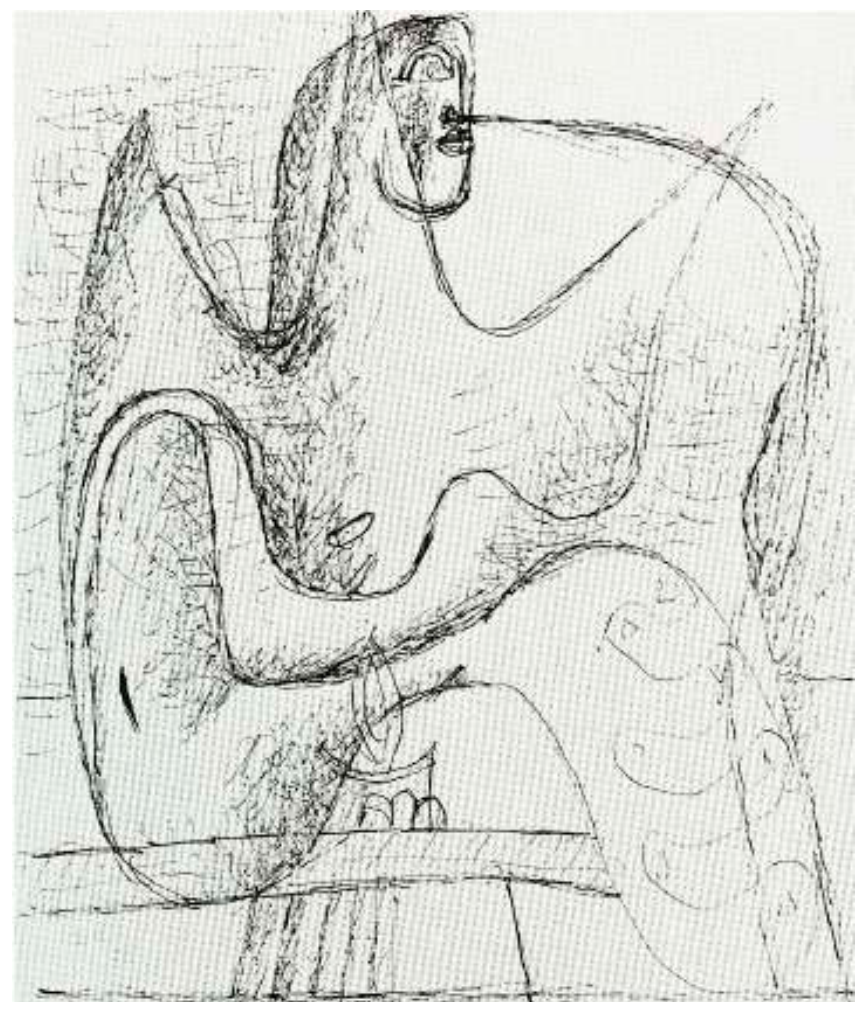




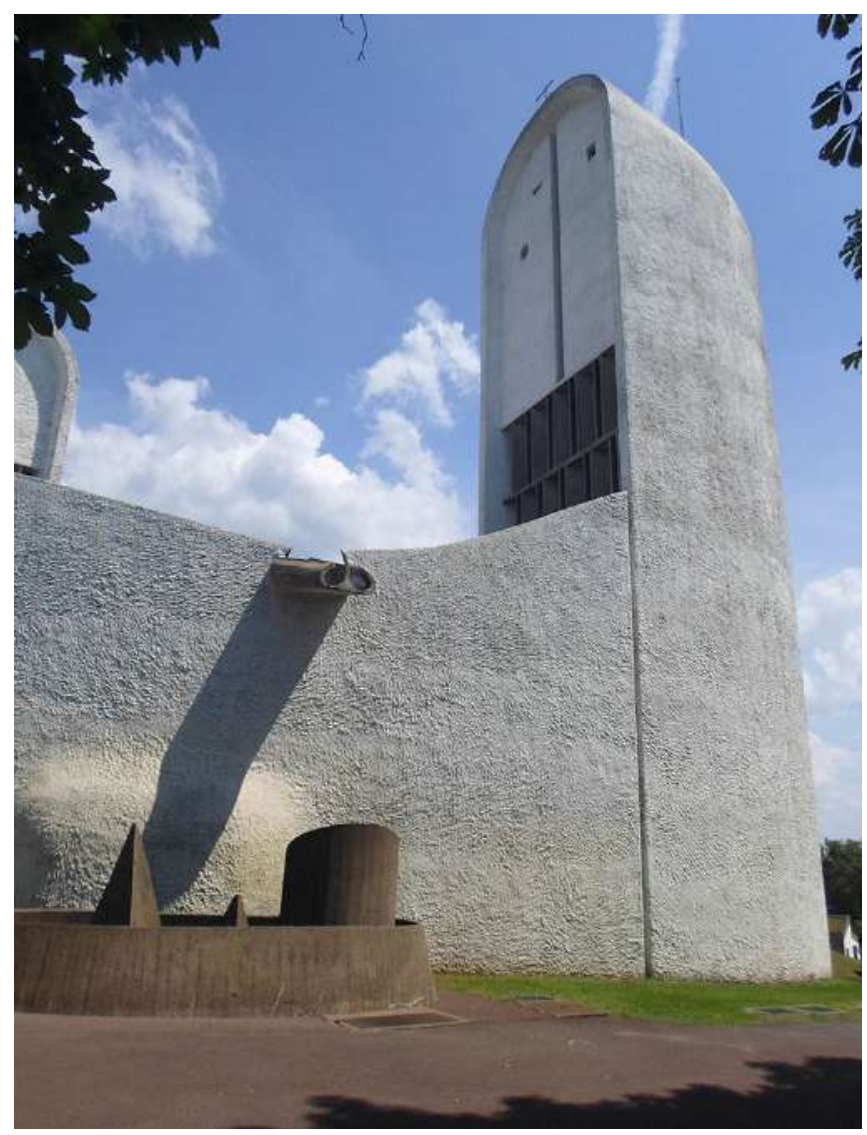

Figura 7. Torre de Ronchamp. Fuente: foto del autor.

A partir de la segunda guerra mundial, Le Corbusier se hizo cada vez más profuso en la utilización de símbolos. Su pintura comenzó a impregnarse de contenidos místicos y misteriosos: 
Acepto las señales, creo en los signos. Porque son la expresión de las realidades vividas // o la evocación de las preguntas sin respuesta //. Me detengo frente al símbolo, frente a la metafísica = imaginación, creación válida en un tiempo y circunstancias, objetos y fetiches de explotación del hombre, tierra de asilo de los escapados, evasores y mitómanos. (Le Corbusier, 1981, p. 128)

La figura mítica del toro tiene un gran protagonismo en la producción iconográfica de Le Corbusier, quien durante un largo período de su vida se vio interesado en la representación del astado. En Tarvono, un pueblo búlgaro que visitó durante el Viaje a Oriente, tomaba fotografías de los búfalos, mirando con reparo las cabezas y sus pronunciadas cornamentas (Daza, 2015). En España, compraba estampas de las corridas de toro que luego dibujaba y volvía a colorear. Entre finales de los Cuarenta y principios de los Cincuenta, por los años de Ronchamp, Le Corbusier realiza otra larga serie de pinturas que titula Taureaux (toros) (figura 8). En esta secuencia en policromía se puede intuir la superposición de figuras, las cuales se vislumbran más claramente en una litografía de Le Poème titulada Unité // (figura 9). Si se comparan ambas representaciones, se aprecian tres franjas: en la superior parece haber la amalgama de la cabeza de una mujer, la luna y los cuernos del toro; en la parte intermedia una cabeza que, por sus proporciones y pico semeja al de un pájaro, un cuervo (como también se le solía Ilamar a Le Corbusier —Corbeau—, y figura con la cual él, en ocasiones, se identificaba), cuyos ojos serían los pechos de la mujer y, a la vez, las fosas nasales del toro. La cabeza del bovino se descubre cuando se gira la imagen 180 grados. Aquí el pintor se vale de la maniobra de girar la figura con la intención de que el animal no sea del todo evidente. 


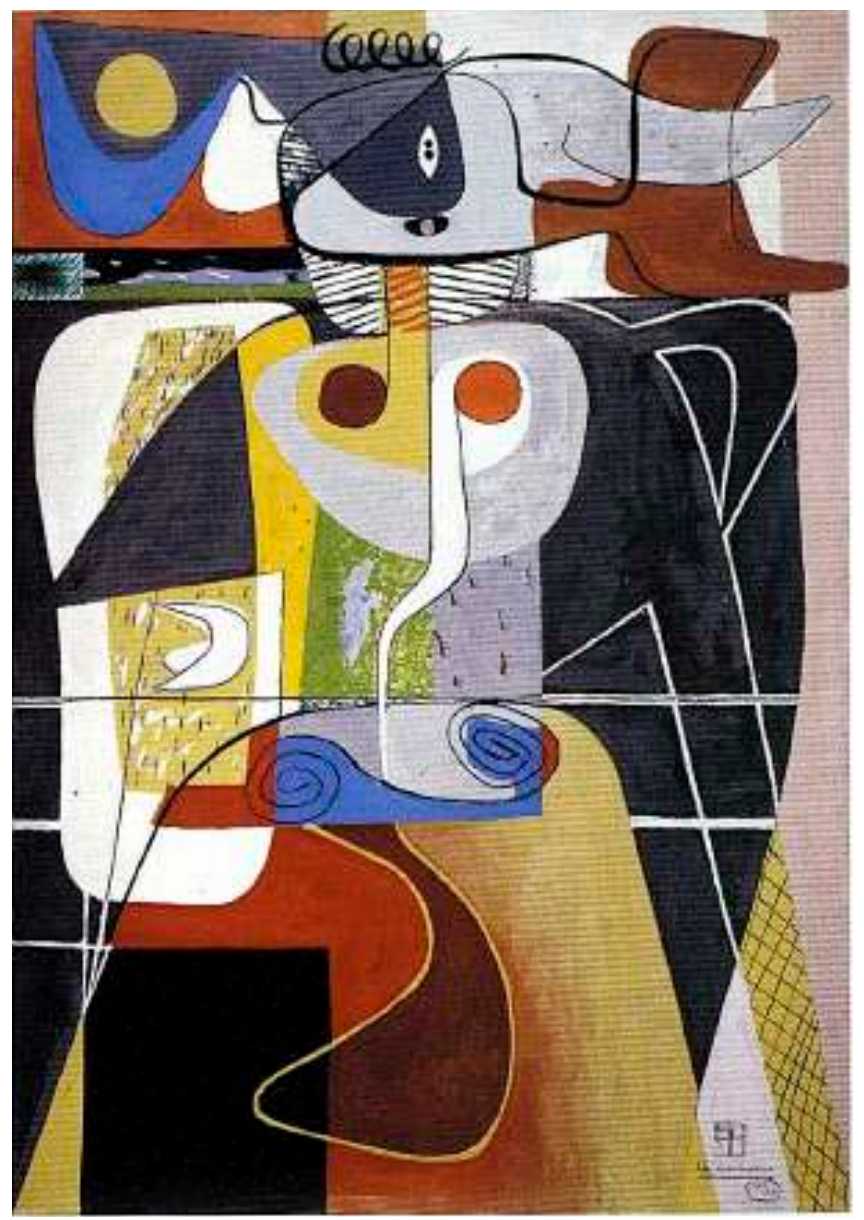

Figura 8. Taureaux II, 1953. Fuente: Fondation Le Corbusier (1997). 


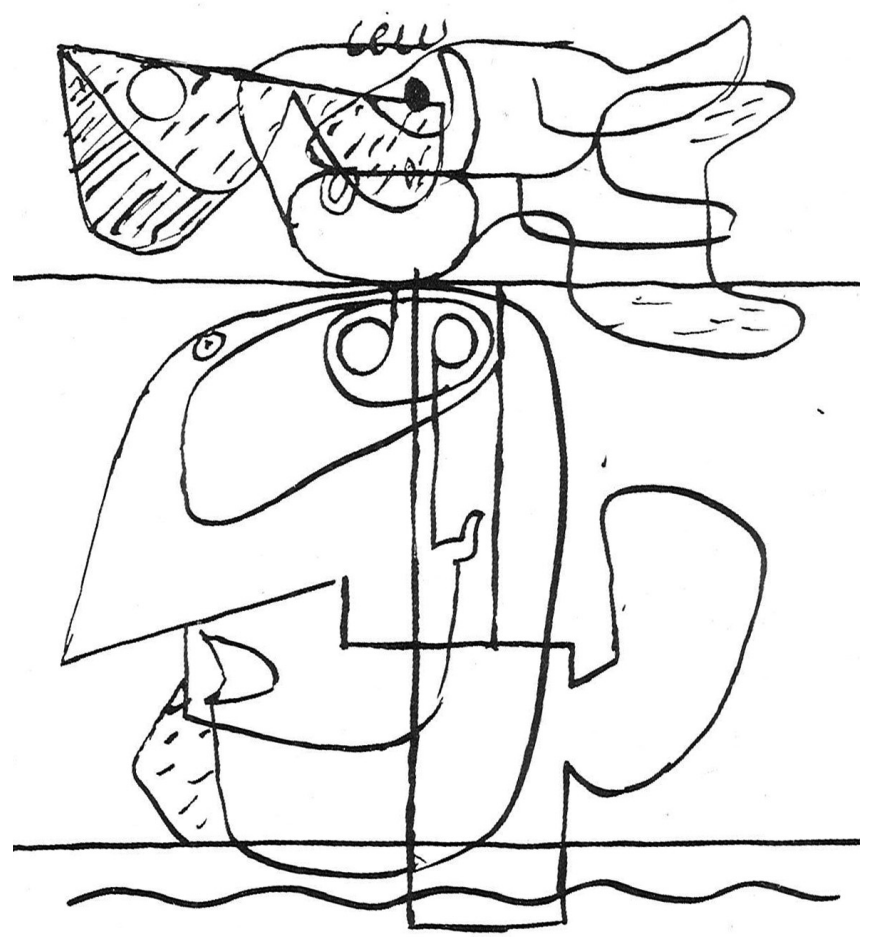

Figura 9. Unité II (FLC). Fuente: Le Corbusier (1947-53).

Esta estrategia de girar la figura del toro, para ocultarla, quedaría al descubierto en un muro de hormigón con relieves en La Casa de la Cultura y la Juventud en Firminy-Vert (1965) (figura 10), donde la cabeza del toro no está girada y se aprecia más claramente la testa del animal con sus fosas nasales y cornamenta, sus rasgos más distintivos, como así lo certifica el propio Le Corbusier en otra 
de sus litografías de Le Poème (figura 11), en la que solo se ven los cuernos y la nariz del animal, y además escribe: "El signo del toro".

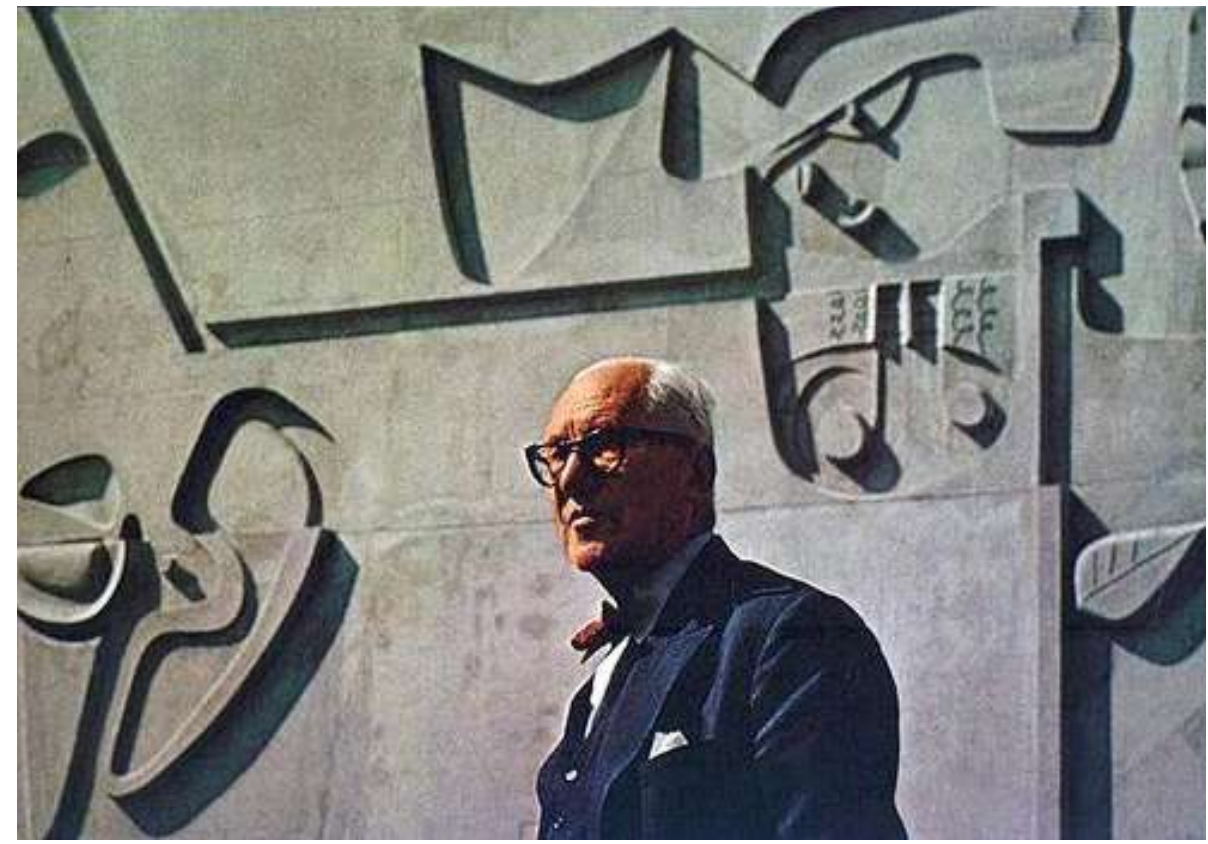

Figura 10. Le Corbusier delante del muro de hormigón con relieve en el que se ven la cabeza del toro. Fuente: Boesiger y Girsberger (1987). Portada. 


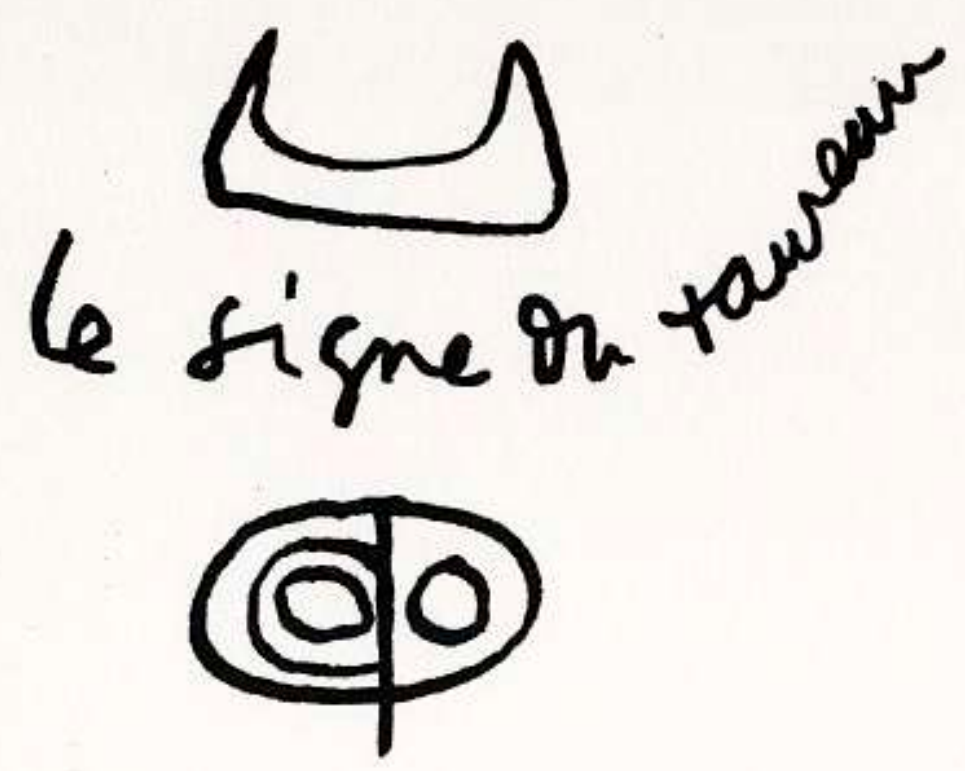

Figura 11. "El signo del toro", litografía en Le Poème. Fuente: Le Corbusier (1947-53).

La explicación a esta enorme atracción que siente el artista por la figura taurina puede encontrarse en otro cuadro. En la pintura titulada Femme Rose (figura 12), están representadas, en primer plano, un par de mujeres, y en el fondo, mostrando sólo los cuernos y las patas, se esconde un toro. Le Corbusier ha dejado una pista que puede llevarnos a descubrir su interés por los toros: en la parte baja de la pintura hay un ovillo que hace un ocho, y en su interior escribió Ariadne y Phasiphae. Es casi seguro que el cuadro sea la representación del mito griego del Minotauro. Las dos figuras femeninas corresponderían 
entonces a Ariadna y su madre Pasífae, los nombres que escribió al interior del ovillo. Una de las mujeres tiene el rostro de la luna, en alusión a que a Pasífae también se le conoce como la Diosa Luna. El toro permanece oculto en el cuadro, como lo estaría el Minotauro en el laberinto. Y el ovillo podría representar la madeja de hilo que Ariadna le entregó a Teseo para que, una vez matara al toro, pudiera encontrar la salida del laberinto.

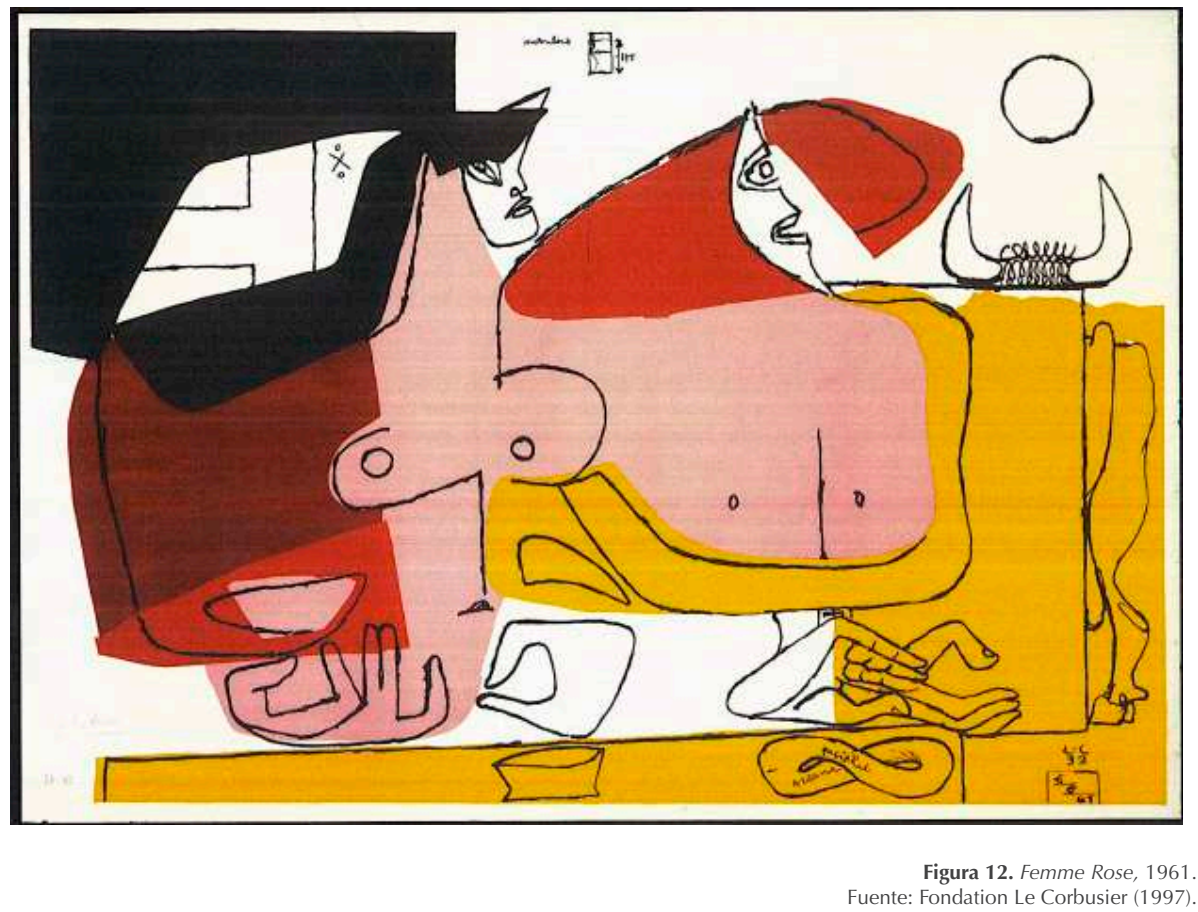

La relación amorosa entre el toro y la mujer (recordemos que el minotauro, mitad hombre y mitad animal, nace de la relación prohibida entre Pasífae y un 
toro) está confirmada en otras de sus pinturas, como en una pintura esmaltada sobre metal que realizó en la Maison de l'Homme / Centro Heidi weber (1967) en Zúrich, o en el amistoso abrazo entre mujer y toro que dibuja en otra de las litografías de Le Poème, titulada Unité I (figura 13). Esta última estampa es de seguro la fuente de la litografía Ilamada Unité II (figura 9), ambas hacen parte de Le Poème. En principio la pareja se muestra reunida, y posteriormente se mezclan en uno solo; de ahí la denominación de esta secuencia.

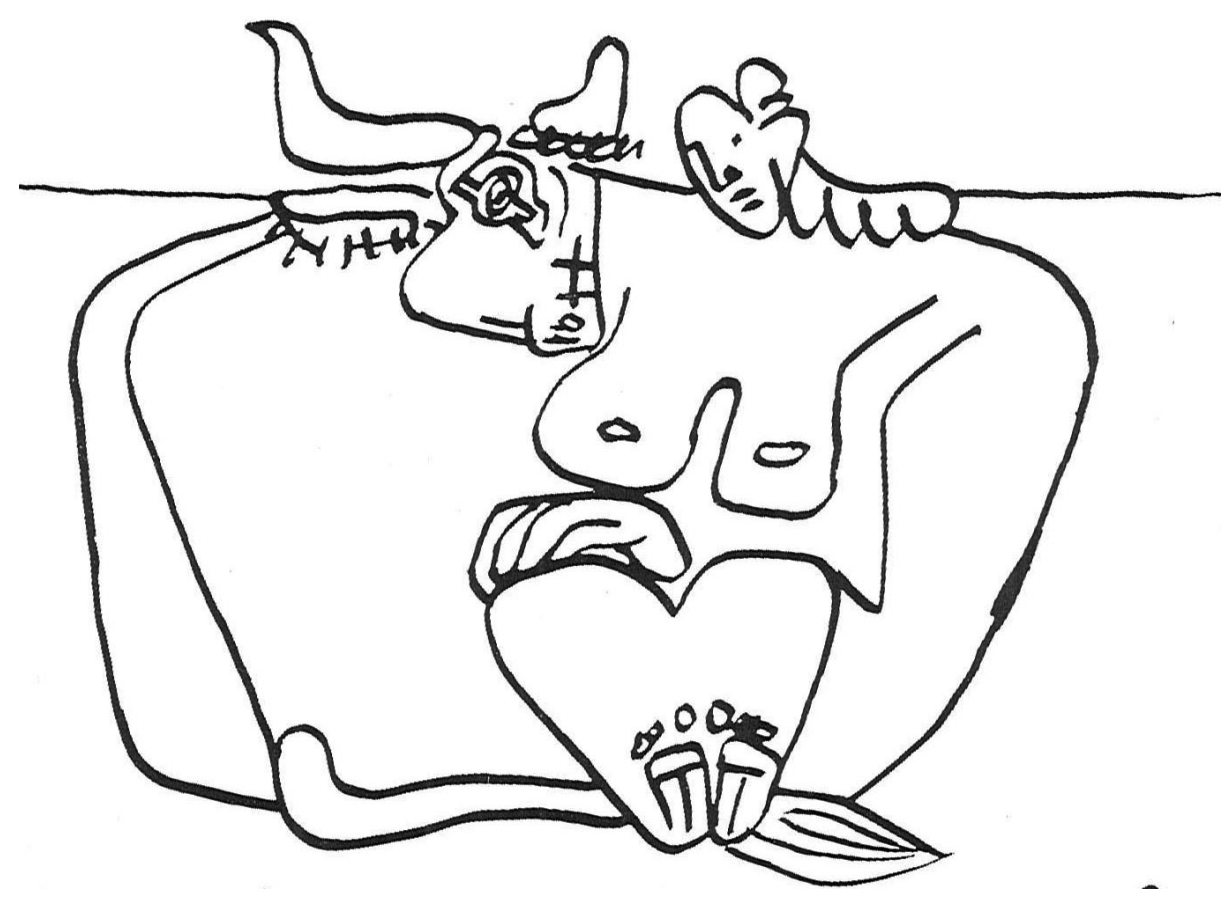

Figura 13. Unité 1 . Fuente: Le Corbusier (1947-53). 
En la obra de le Corbusier son múltiples las referencias a la mitología griega. En sus carnets de viajes hay constantes notas sobre estos personajes míticos, sin contar con que en su biblioteca tenía una gran cantidad de libros dedicados al tema (Turner, 1977). En la Capilla de Ronchamp están presentes, de velada manera, las figuras femenina y taurina. La cubierta, por uno de sus costados, tiene el perfil del cuerno del toro; las torres contienen la forma antropomórfica de Icône; la proa del edificio con sus torres replica el perfil de la diosa Luna; la gárgola de la cubierta (figura 14), si se mira de frente, también emula los cuernos y las fosas nasales del toro, y a la vez los pechos de la mujer de la serie Taureax. Mujer y animal, protagonistas del mito griego del minotauro, terminan estando mezclados e imbuidos en las formas de la Capilla.

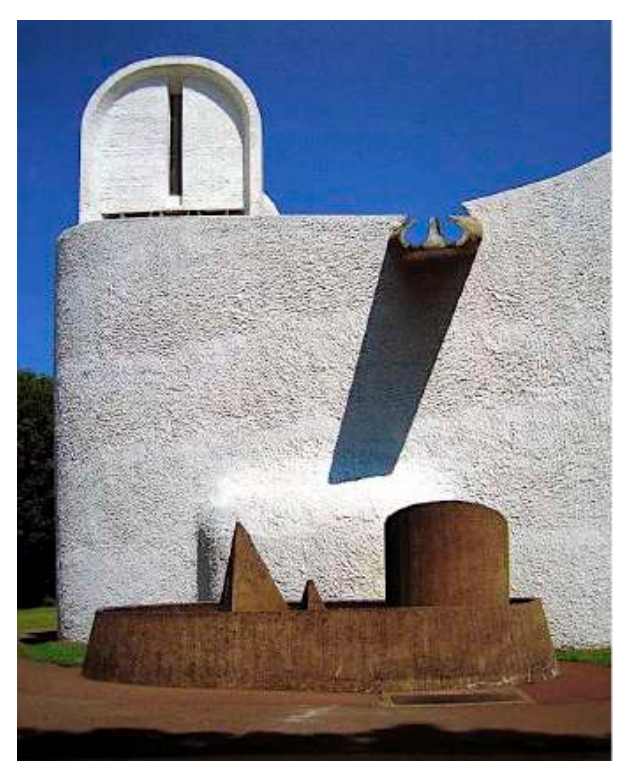

Figura 14. Gárgola y cisterna de la Capilla de Ronchamp. Fuente: foto del autor. 


\section{Escultura}

En 1947, Joseph Savina, ebanista bretón, le propone a Le Corbusier realizar unas cuantas esculturas a partir de algunos de sus cuadros. El pintor acepta el ofrecimiento que le permitiría explorar tridimensionalmente las formas que denominaba "acústicas". La relación de trabajo era bastante particular, pues los dos residían en ciudades diferentes. Las esculturas eran modeladas por Savina en Bretaña, con base en croquis que Le Corbusier le enviaba desde París; a la vuelta, el ebanista enviaba fotografías de las piezas esculpidas, para que el pintor hiciera los comentarios y correcciones que fuesen necesarios. Terminadas de moldear, las piezas eran pintadas por alguno de los dos. En contadas ocasiones pudieron reunirse para trabajar juntos.

Le Corbusier consideraba la escultura como un paso intermedio entre la pintura y la arquitectura. Las pinturas, bidimensionales, cobraban corporeidad en las esculturas y éstas, a su vez, servían de pruebas, de laboratorio de experimentación formal cuya última y principal finalidad era la arquitectura. La Capilla de Ronchamp sería el caso más notable de estas múltiples transformaciones: "estoy seguro que usted está sobre un rastro heroico de la escultura que conduce a la gran arquitectura" —le escribió a Savina (FLC, 1984, p. 98).

Pocos años antes de Ronchamp, Le Corbusier estaba realizando una serie de esculturas en donde involucraba el concepto de la acústica: "Este tipo de escultura encaja en lo que Ilamo la plástica acústica, es decir, las formas que emiten y que escuchan" (FLC, 1984, p. 98). En definitiva, se trataba de formas que se ponen en estrecha relación con el espacio que las rodea, y así parece confirmarlo cuando escribe: “(...) especies de escultura 'de naturaleza acústica', es decir, proyectan a lo lejos el efecto de sus formas y, a cambio, reciben la presión de los espacios circundantes" (Le Corbusier, 1966, p. 240). 
Las primeras esculturas nacieron a partir de la serie de pinturas denominada Ozon. La escultura número 4, titulada Ozon opus I (figura 15), se origina a partir de una de estas pinturas, en la que Le Corbusier separa la oreja y la boca de una cabeza con figura humana, o sea los órganos que emiten y reciben el sonido, y los exagera en tamaño (figura 16). Estas figuras se irían transformando paulatinamente hasta perder su referencia inicial. Al artista le interesaba que las esculturas no tuviesen, necesariamente, la connotación de figura humana. No tendrían que ser "personas" ni "cosas" —le escribió a Savina—, simplemente deberían ser formas comprometidas con el espacio: “(...) el punto de partida no es la cabeza de un pájaro o de un perro y es inútil acercarse a tal parecido. Por el contrario, es preciso que el objeto sea sin significación precisa." (FLC, s.f.).

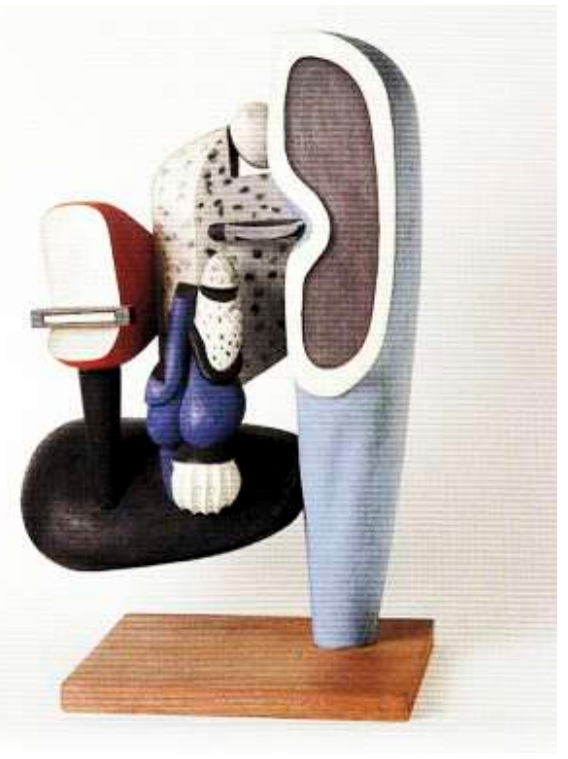

Figura 15. Escultura Ozon opus I. Fuente: Fondation Le Corbusier (1997). 


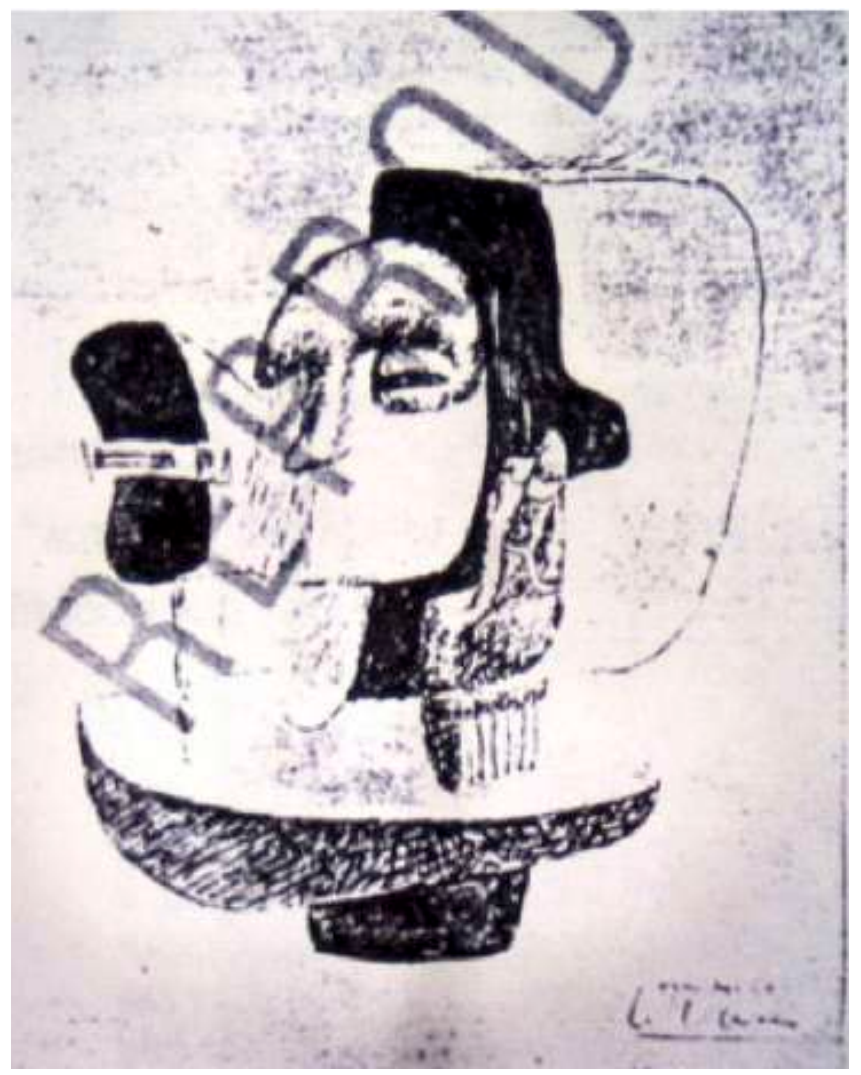

Figura 16. Dibujo de la serie Ozon. Fuente: Fondation Le Corbusier (1997).

Estas formas curvas, cóncavas y convexas de la escultura, también están presentes en la Capilla de Ronchamp, la cual, mediante sus ondulaciones, entra en relación con el espacio que la rodea, escuchando o hablando al paisaje circundante. 


\section{Arquitectura. "Fenómeno de acústica visual"}

Tal vez, la primera vez que Le Corbusier trabajó la acústica en sus edificios fue en el año 1926 en la propuesta presentada para el concurso del Palacio de las Naciones en Ginebra. En su libro "Una Casa - Un Palacio" hace una larga disertación sobre el manejo de la acústica, explica cómo las formas circulares, por ejemplo, no son nada apropiadas para el sonido, pues las ondas rebotan de manera descontrolada contra las paredes y se concentran en el medio, produciendo efectos de resonancia y reverberación. En cambio, la forma trapezoidal del auditorio, que utilizó para el Palacio de las Naciones, es la más óptima para que las ondas sonoras, emitidas por el orador desde el lado más corto, viajen más rápidamente hasta los oídos de los auditores, de una manera homogénea, sin tropiezos ni reverberaciones. La sección elíptica de la cubierta del auditorio ayuda en el encauzamiento de las ondas, las cuales se reflejan sobre la superficie curvada regresando hacia el público: "La esfera de la onda sonora es una bola de billar; ella rebota en cada superficie que encuentra, de acuerdo con el ángulo de incidencia; exactamente como la bola de billar" (Le Corbusier, 1928, p. 109).

En 1931 Le Corbusier vuelve a hablar de acústica en su propuesta urbana para Argel. Los grandes edificios, organizados a partir de una columna vertebral, se curvan, dejando que la parte cóncava — la abierta - mire hacia el exterior del conjunto (figura 17). La acústica en este caso pasa a ser una metáfora: las concavidades, que semejan las formas del pabellón de la oreja, conchas, o antenas receptoras, acogen el eco del paisaje y a la vez emanan sonidos: "estas curvas de los edificios son como conchas sonoras; ellas envían sonidos (o vistas) a lo lejos; desde lejos, ellas reciben todos los sonidos (o vistas)" (Le Corbusier, 1948, p. 16). 


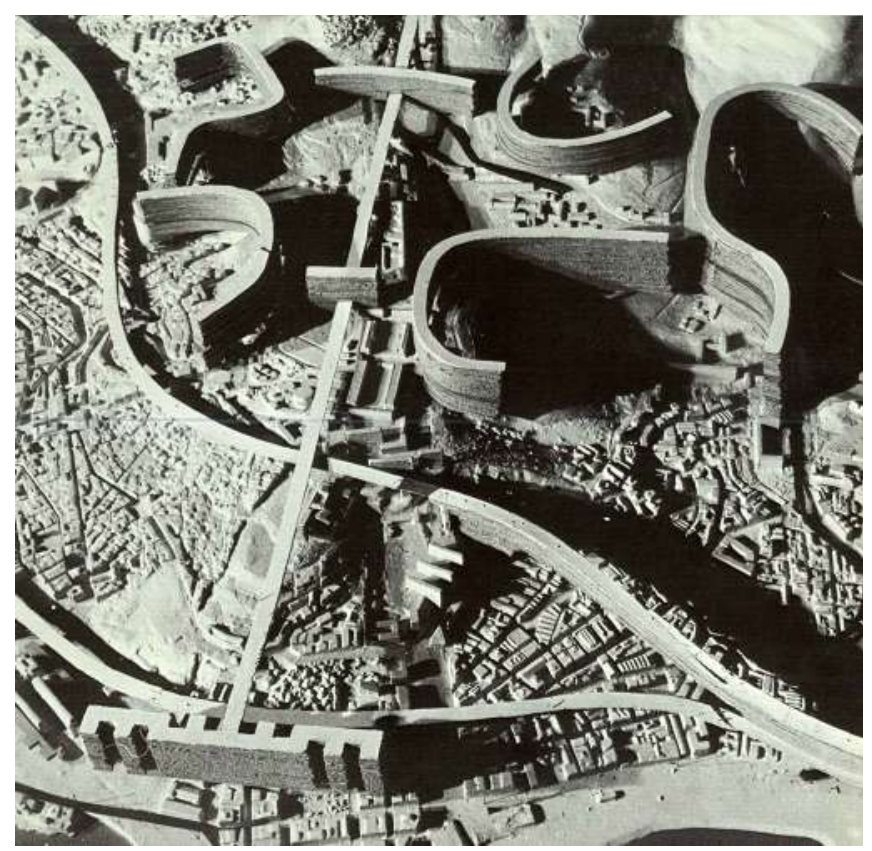

Figura 17. Propuesta urbana Plan Obus en Argel. Fuente: Le Corbusier (1935).

En su libro "El Poema del ángulo recto", Le Corbusier dibuja otra concavidad en una oreja pronunciada, casi desprendida de la cabeza de una mujer, dando a entender su autonomía (figura 18). El tamaño de esta oreja se asemeja al de la cabeza de la mujer y su silueta se puede ver como otra cabeza. Entonces, la cavidad se convierte en la boca, en una oreja que habla, igual que, en el juego de las asociaciones entre los órganos que empleaba el maestro, se habla de "acústica visual", es decir, de los sonidos que se ven o de los ojos que escuchan. 


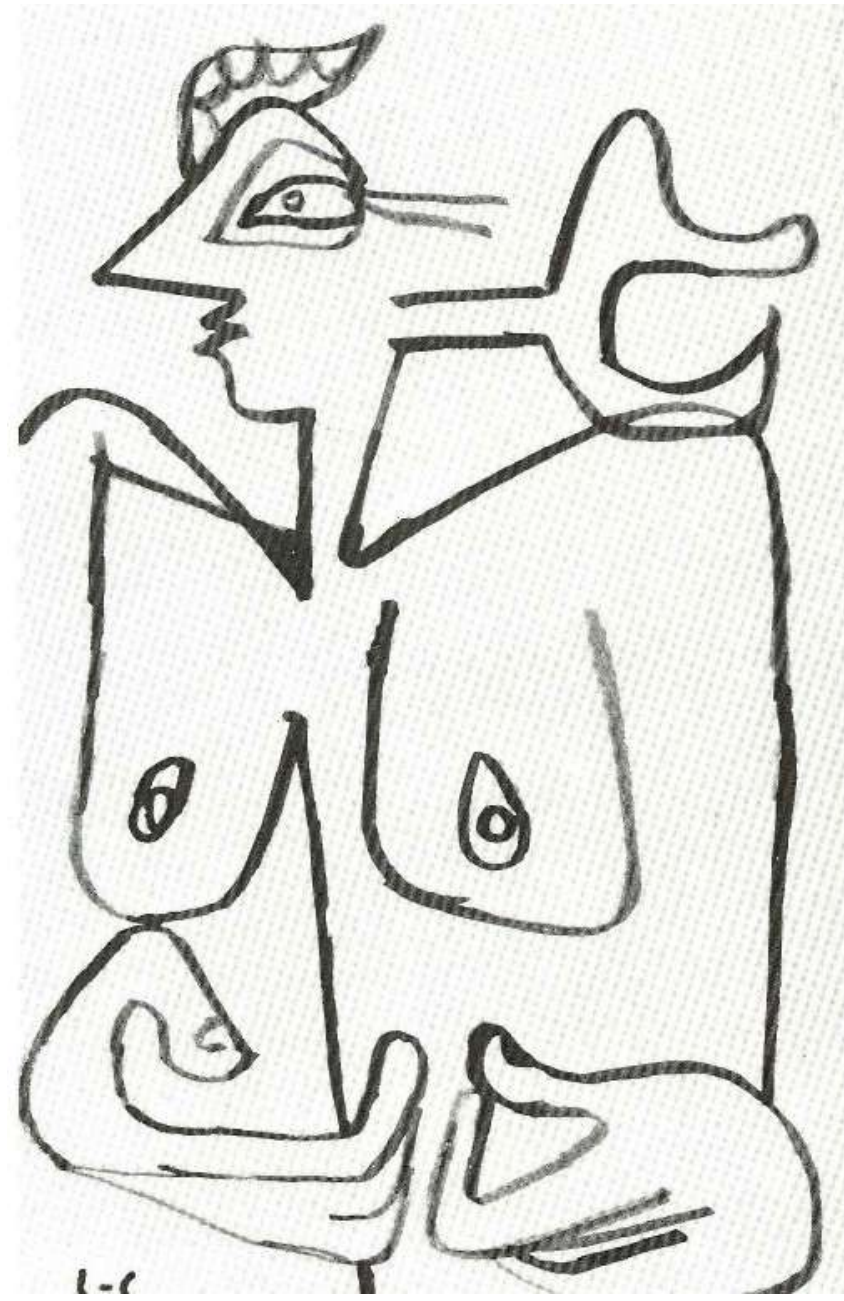

Figura 18. Litografía en "El Poema del ángulo recto". Fuente: Le Corbusierb (1947-53). 
En su libro Aircraft (1935), Le Corbusier hace otra referencia al fenómeno sonoro; publica la fotografía de una máquina de guerra que dispone sus antenas parabólicas hacia diversos costados del firmamento (figura 19). Al margen escribe:

Las leyes más exactas de la acústica ayudarán en la defensa espacial. Al igual que el oído de un perro o de un caballo, las conchas sonoras giran sus tímpanos hacia determinados cuadrantes del horizonte. Los maravillosos dispositivos mecánicos de los seres humanos son solo el reflejo de los mecanismos de la naturaleza. (Le Corbusier, 1935, p. 19)

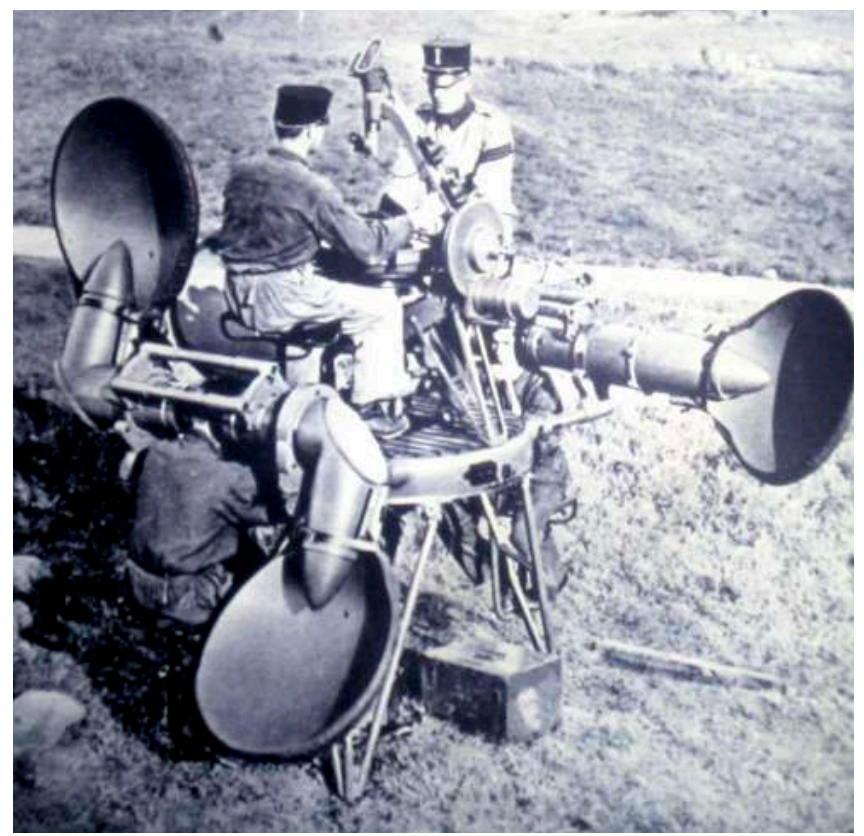

Figura 19. Máquina de guerra con sus antenas parabólicas. Fuente: Le Corbusier (1935). 
Las paredes cóncavas y la cubierta de la Capilla de Ronchamp son también como unas especies de antenas parabólicas, que recogen las ondas emitidas por el paisaje y la cúpula celeste, y a su vez envían ondas sobre el firmamento y el lugar.

Es posible rastrear un hilo conductor que va desde las preliminares formas de la pintura y la escultura, denominadas acústicas, hasta el definitivo aspecto que la Capilla adopta. Si se compara por ejemplo la pintura titulada Acoustic Forms (1946) (figura 20), con la planta de la Capilla (figura 21), podría entreverse que ambas figuras están constituidas por líneas onduladas que forman concavidades y convexidades, que en ambas hay una esquina punzante, que en las dos está presente el perfil del pabellón de una oreja. Es más, si se hiciera el ejercicio de imaginar el reflejo que produciría un espejo en la parte superior del cuadro, se descubriría que la silueta de la pintura es prácticamente idéntica al contorno de la planta (Coll, 1994). Ya hemos visto que no es de extrañar este tipo de giros y reflejos, pues Le Corbusier solía recurrir constantemente a ellos como estrategia de diseño. Esto no significa que el arquitecto estuviera replicando directamente formas de la pintura en su arquitectura, simplemente se trataba de ejercicios plásticos que seguramente quedaban en su inconsciente, y luego afloraban con cierta espontaneidad. 


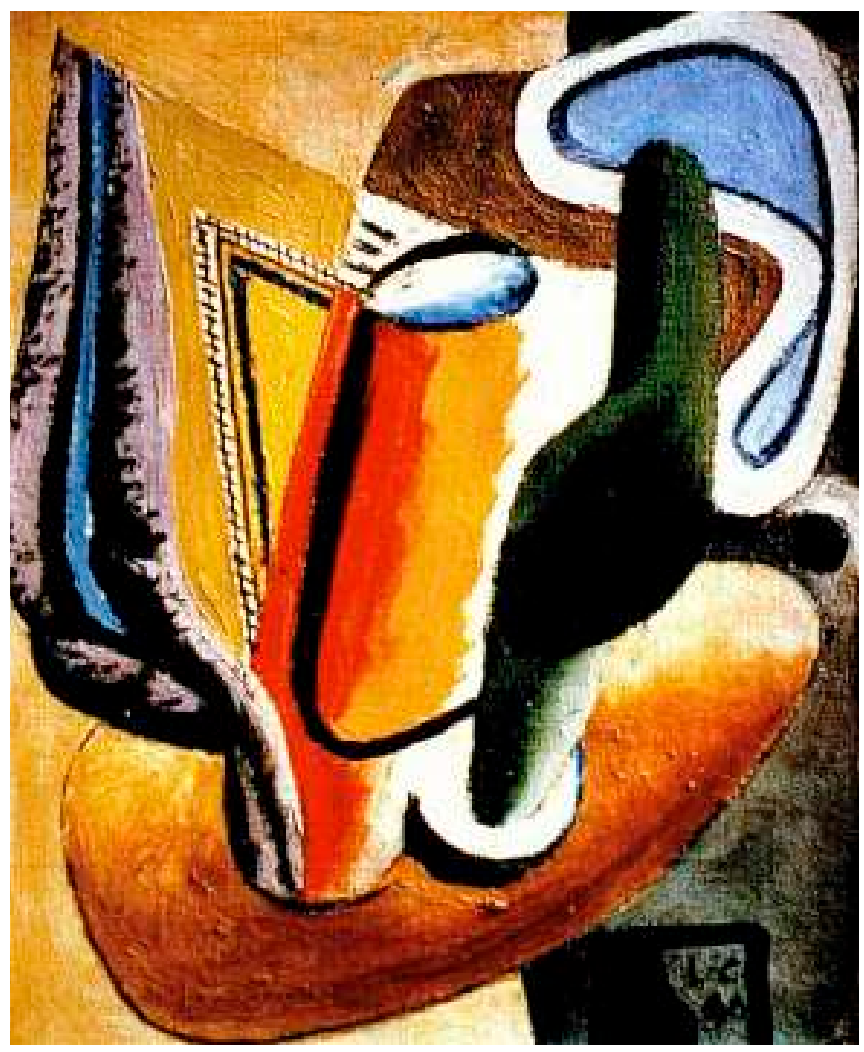

Figura 20. Acoustic Forms. Fuente: Fondation Le Corbusier (1997). 


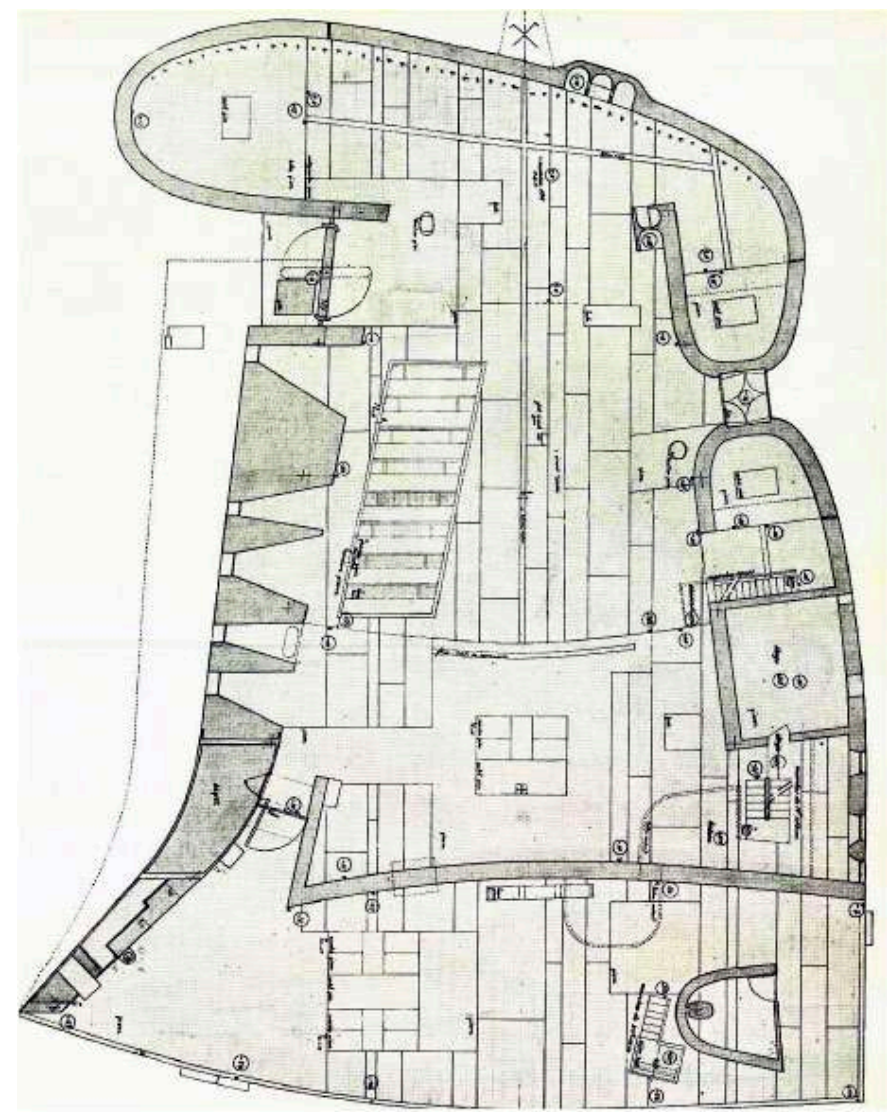

Figura 21. Planta de la Capilla. Fuente: Le Corbusier (1957).

En la planta definitiva de la Capilla también podemos constatar la silueta punzante del cuerno del toro. 


\section{"El espacio Indecible"}

El fenómeno acústico no se da solamente en un único sentido, del rededor hacia la obra. Cuando el edificio está bien proporcionado, éste también emana una respuesta sobre el lugar, estableciendo una relación recíproca con el paisaje, un diálogo permanente. Esta es la condición por la cual la Capilla de Ronchamp extiende sus efectos sobre el horizonte y lo pone a "vibrar", es lo que Le Corbusier denominó "el espacio indecible":

\section{Espacio indecible - Ronchamp (1957)}

Este es preparado por las proporciones. La proporción es una cosa inefable. "El espacio indecible" es una realidad descubierta en el curso del camino. Cuando una obra se encuentra en su máxima intensidad, por su proporción, por la calidad de su ejecución, por su perfección, se produce un fenómeno de espacio indecible: Los lugares se ponen a irradiar, físicamente ellos irradian. Ellos determinan lo que yo llamo "el espacio indecible", es decir un choque que no depende de las dimensiones, sino de la calidad de la perfección. Este es el reino de lo inefable. (Le Corbusier, 1962, p. 35-36)

En 1946 Le Corbusier publica un artículo en la revista L'Architecture d'Aujourd'hui que se titula L'espace indicible. Comienza el artículo haciendo hincapié sobre la materia fundamental con que se construye la arquitectura, la escultura y la pintura: el espacio.

La arquitectura, la escultura y la pintura dependen específicamente del espacio, están atadas a la necesidad de gestionar el espacio (...) Lo que se dirá aquí de esencial, es que la clave de la emoción estética es una función espacial (...) El arte es ciencia espacial por excelencia. (Le Corbusier, 1946, p. 9)

A continuación, va detallando la manera en que la obra y su entorno se modifican mutuamente:

Acción de la obra (arquitectura, escultura o pintura) sobre el entorno: las ondas, los gritos o los clamores (El Partenón sobre la Acrópolis de Atenas), sus rasgos brotando como por una radiación, como accionados por una explosión; El sitio cercano o lejano es sacudido, afectado, dominado o acariciado. Reacción del medio: los límites del espacio en rededor, sus dimensiones, el lugar con 
los diversos pesos de sus fachadas, las extensiones o las laderas del paisaje y hasta los horizontes desnudos de las planicies o aquellos crispados por las montañas, todo el ambiente viene a pesar sobre ese lugar donde está una obra de arte, signo de una voluntad humana, que le impone sus profundidades o proyecciones, sus densidades duras o blandas, sus violencias o sus dulzuras. Se presenta un fenómeno de concordancia, preciso como las matemáticas. (Le Corbusier, 1946, p. 9)

Como lo escribe en el apartado que titula "Acción de la obra", el lugar donde Le Corbusier aprendió este fenómeno de concordancia entre el edificio y el paisaje fue durante su viaje a Oriente, en la Acrópolis de Atenas, mientras observaba cómo el Partenón extiende sus efectos hacia el mar, hacia el espacio circundante (figura 22).

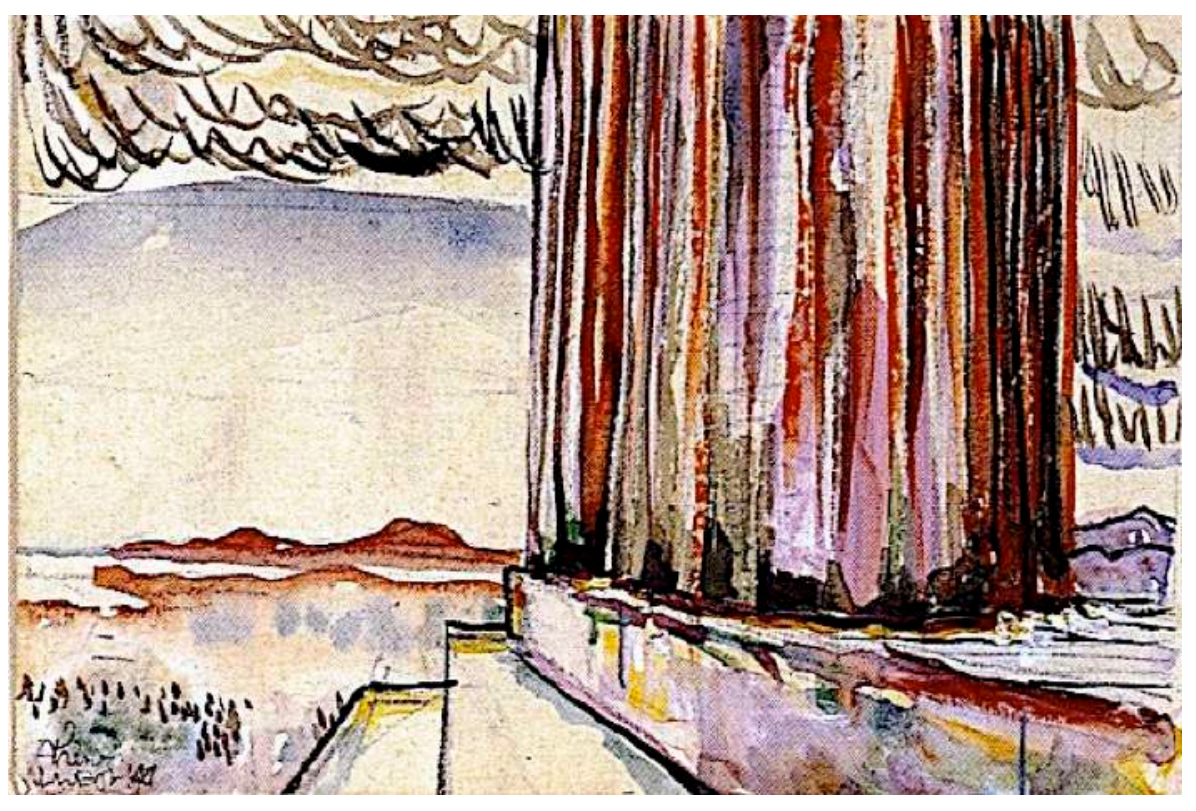

Figura 22. Acuarela del Partenón de la acrópolis de Atenas en relación con el paisaje. Fuente: Le Corbusier (1966). 
El eje de la Acrópolis va del Pireo al Pentélico. Del mar a la montaña, de los Propileos, perpendiculares al eje, a la lejanía del horizonte, al mar. Horizontal perpendicular a la dirección que os ha impuesto la arquitectura en el lugar donde estáis, percepción ortogonal que hay que tener en cuenta. Alta arquitectura: la Acrópolis extiende sus efectos hasta el horizonte. (Le Corbusier, 1923, p. 151)

La concordancia entre el edificio y el paisaje sucede por una reacción desencadenante, provocada por las cualidades excepcionales del edificio, el cual irradia su halo sobre el lugar que lo rodea y lo hace vibrar. Esta relación entre la obra y su entorno se establece en el marco de un espacio diferente al que convencionalmente conocemos. El espacio —el vacío-como usualmente se conoce, viene determinado por los límites de la materia, por las superficies contingentes, y cualificado por los colores, los materiales, las texturas, etc. Le Corbusier habla del "espacio indecible" como de un espacio inabarcable, inconmensurable, que no viene dado por los términos de magnitud, sino por una estrecha relación en la cual el edificio y el paisaje se afectan mutuamente. Habla de una dimensión desconocida por la que el espacio se evade, escapa a cualquier límite que pretenda contenerlo:

La cuarta dimensión parece ser el momento de evasión ilimitado provocado por una consonancia excepcional de los medios plásticos utilizados en la obra y por ellos desencadenado (...) Entonces una profundidad sin límites se abre, borra los muros, atrapa las presencias contingentes, logra el milagro del "espacio indecible". (Le Corbusier, 1946, p. 10)

"El espacio indecible" es, como bien lo dice su nombre, un espacio inaprensible, inabarcable aún por las palabras. En el supuesto de que se pudiese enunciar, definir en toda su extensión, se le estarían fijando unos límites, y entonces dejaría de existir, ya no se trataría de "El espacio indecible". 
De la misma manera que el Partenón de la Acrópolis establece una estrecha relación con el espacio circundante, el "espacio indecible" también se puede percibir en Ronchamp. Una vez se sube a la cima de la colina, la Capilla, mediante su concavidad, da un abrazo de bienvenida al visitante. La mirada del observador se pasea por el muro blanco y la cubierta de hormigón (que representa el cuerno del toro) hasta ser conducida de nuevo hasta el paisaje circundante. Entonces se descubre ese diálogo inefable entre el edificio y el paisaje, entre la arquitectura y la naturaleza (figura 23).

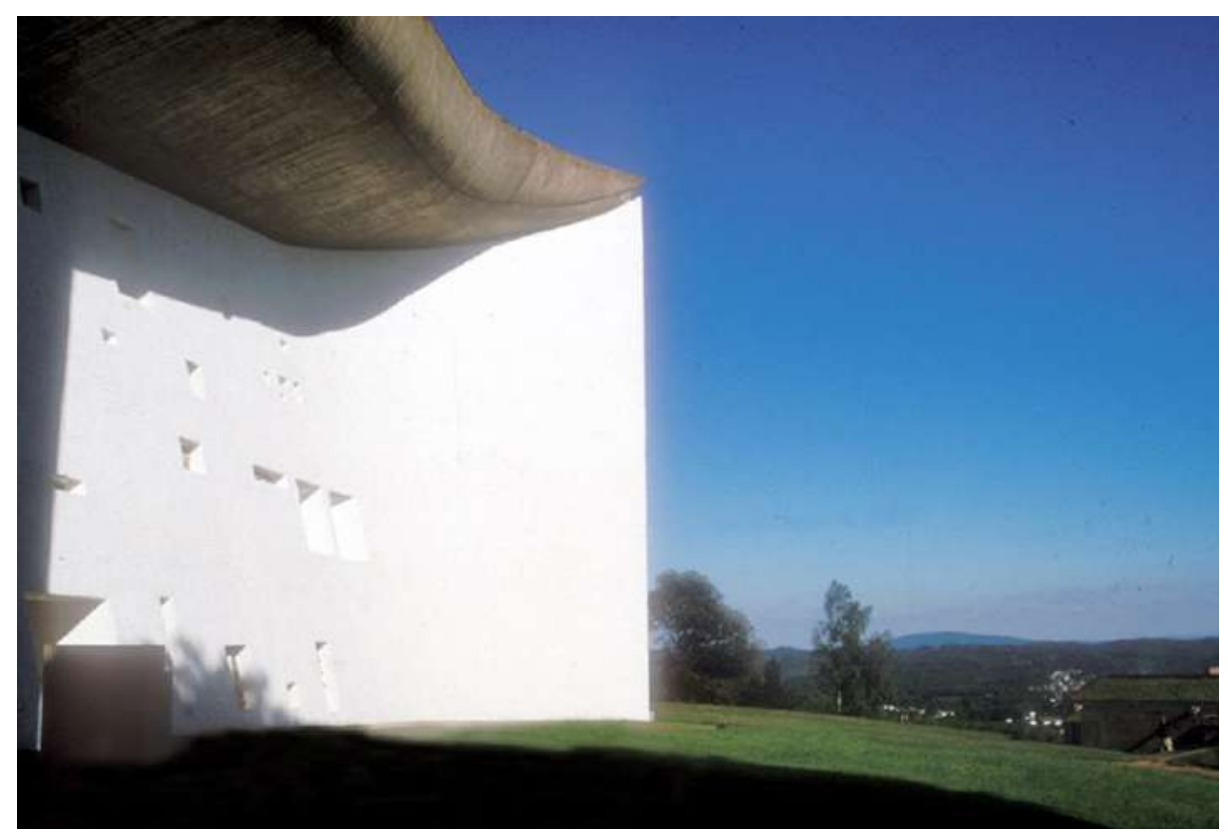

Figura 23. La Capilla de Ronchamp en relación con el lugar. Fuente: foto del autor 


\section{Conclusiones}

Está claro que Le Corbusier estableció un procedimiento de diseño a partir de un laboratorio de exploración formal, el cual denominaba la 'búsqueda paciente', a partir de sus actividades alternas que ejercitaba en la pintura y la escultura, las cuales daban paso a respuestas en la arquitectura.

Resulta manifiesta la influencia que, a partir de la pintura y la escultura, las actividades que Le Corbusier mantenía casi en secreto, estos otros campos del arte, influyeron en el producto final de la arquitectura, específicamente en la Capilla de Ronchamp donde puede rastrearse una serie de influencias de las series de pinturas y esculturas tituladas Ozon y Obu, formas denominadas como "acústica visual" que van a confluir luego en la conformación de la Capilla.

Así mismo es demostrable la estrecha relación que guardan las formas de la Capilla con temas místicos, trabajados por Le Corbusier poco antes de Ronchamp. como son las series de pinturas Icône, y Taureaux, referidos a las apologías de la diosa Luna y el minotauro en la mitología griega.

En los tres campos del arte explorados por Le Corbusier, como son las pinturas bidimensionales, las esculturas tridimensionales a una escala reducida, y luego la arquitectura en mayor tamaño, se puede evidenciar que los cuerpo dotados de líneas y superficies cóncavas y convexas, provenientes de la descomposición de la figura humana, más concretamente a partir de los órganos de emisión y recepción del sonido, de la boca y el oído, formas denominadas de "acústica visual", se ponen en estrecha relación con el espacio circundante.

Esta relación que se establece entre la obra de arte y su entorno supera en buena medida nuestra apreciación del espacio hasta ahora reconocible — medible y cualificado_ y pasa a tener una connotación inmaterializada, 
casi metafísica, por la cual el objeto y su entorno se modifican mutuamente en algo que Le Corbusier denominó "El espacio indecible".

\section{Referencias}

Boesiger, W. y Girsberger, H. (1987). Le Corbusier 1910-1965. Barcelona: Gustavo Gilli.

Coll, J. (1994). Le Corbusier: la forma acústica [Tesis de doctorado, Universidad Politécnica de Cataluña]. URL del repositorio institucional

Daza, R. (2015). Tras el Viaje de Oriente. Charles Édourad Jeanneret - Le Corbusier. Barcelona: Arquitesis.

Fondation Le Corbusier. (1984). Le Corbusier Savina, dessins et sculptures. Paris: Philippe Sers.

Fondation Le Corbusier. (s.f.). Dossier Ronchamp. http://www.fondation lecorbusier.fr/corbuweb/morpheus.aspx?sysld=13\&IrisObjectld=5147\&sy sLanguage $=$ fr-fr\&itemPos $=13$ \&itemCount $=78 \&$ sysParent Name $=\&$ sysParent $\mathrm{Id}=64$

Hervé, L. (1970). Le Corbusier: I'artiste, l'écrivain. Neuchâtel: Griffon.

Ingersoll, R. (1990). Le Corbusier, A Marriage of countours. New York: Princeton Architectural Press.

Le Corbusier. (1923). Vers une Architecture, Paris: G. Cres.

Le Corbusier. (1928). Une Maison-un Palais. Paris: G. Cres.

Le Corbusier. (1935). Aircraft. London/New York: The Studio.

Le Corbusier. (1935). OEuvre Complète. Zurich: Les editions d'Architecture/ Artemis. 
Le Corbusier. (1946). L'espace Indicible. En Art. Numéro Hors-série de L'Architecture d'Aujourd'hui (pp. 9-17). Boulogne-sur-Seine: I'Architecture d'Aujourd'hui.

Le Corbusier. (1948). Unité. En Art. Numéro Hors-série de L'Architecture d'Aujourd'hui (pp. 9-17). Boulogne-sur-Seine: I'Architecture d'Aujourd'hui.

Le Corbusier. (1947-1953). Le Poème de l'angle droit, Tériade Editeur, Paris (reed. Fondation Le Corbusier / Ed. Connivences, 1989).

Le Corbusier. (1956) Chapelle n.-du Haut à Ronchamp, Cahiers Forces Vives, s.I., Desclée de Brower

Le Corbusier. (1957). Ronchamp, Les carnets de la recherche patiente. Zürich: Girsberger.

Le Corbusier. (1962). Catálogo expo Le Corbusier. París: MNAM.

Le Corbusier. (1966). Le Voyage d'Orient. París: Editions Forces Vives.

Le Corbusier. (1981). Le Corbusier Carnets. París: FLC/Electa.

Moore, R. (1979). Le Corbusier. Myth and Meta Architecture. The late period (1947-1965) [Tesis en Filosofía, University of Maryland]. URL del repositorio institucional.

Petit, J. (1957). Le Corbusier lui-même. Ginebra: Rousseau

Petit, J. (1968). Le Corbusier, Suite de Dessins. Genève: Panoramas Forces Vives.

Turner, P. V. (1977). The Education of Le Corbusier. New York: Graland.

Wogenscky, A. (1987). Les mains de Le Corbusier. París: Le Moniteur Editions.

Como citar: Sarmiento-Ocampo, J. A. (2020). Síntesis de las artes en la Capilla de Ronchamp. Revista KEPES, 17(22), 427-464. https://doi.org/10.17151/kepes.2020.17.22.16 